NENAD Ž. PETROVIĆ

Institut za strategijska istraživanja

Beograd, Neznanog junaka 38

\title{
PODUHVAT „GAMA“ \\ Obaveštajna akcija JNA u Budimpešti 1956-1957. - nepoznati dokumenti Vojnog arhiva -
}

U leto 1953, tek nekoliko meseci po smrti Josifa Visarionoviča Džugašvilija - Staljina, došlo je do prvih komešanja unutar Istočnog bloka (u tom času još uvek ne formalno vojnog saveza). Demonstracije građevinskih radnika u Istočnom Berlinu, njihovo brutalno gušenje, potom kao jedna od posledica zbacivanje i likvidacija Lavrentija Berije (viđenog kao Staljinovog naslednika), demonstracije u Poljskoj - nagoveštavali su još burnija previranja. Juna 1953, komunistički disident pod režimom Maćaša Rakošija (Matyas Rakosi), profesor Imre Nađ (Imre Nagy) vraćen je u partiju i preuzima predsedavanje vladom. Međutim, ubrzo biva smenjen jer je partijsko rukovodstvo procenilo da Nađ suviše popušta pred zahtevima koji su stizali sa desna. Tri godine kasnije, uz podrazumevajući blagoslov Hruščova, definitivno odlazi sa vlasti Staljinov kadrovik Rakoši. Istovremeno, jugoslovenski predsednik Tito tokom uzvratne posete Hruščovu vodi razgovore i o situaciji u Mađarskoj. Hruščov je znao, ili barem naslućivao, kolika je „upućenost" jugoslovenskog rukovodstva u mađarske prilike. Prilikom jedne kasnije Titove "turističke" posete Krimu, sovjetska strana vešto namešta sastanak Broza i novog mađarskog šefa partije Erne Gerea. Tom prilikom je dogovoren susret dve državno-partijske delegacije u Beogradu, do kojeg će doći između 15. i 22. oktobra 1956. Odmah po povratku delegacije iz Jugoslavije događaji su se počeli munjevito odigravati.

Tog 23. oktobra, već pripremljene manifestacije podrške demonstracijama i zahtevima iz Poznanja (Poljska), pretvorile su se u oružanu pobunu koja je sa kraćim zatišjima potrajala do početka novembra. U međuvremenu su se odigrale dve sovjetske vojne intervencije: 23/24. oktobra na zahtev novoformirane vlade Imre Nađa, i druga 3/4. novembra bez formalne saglasnosti Nađeve vlade ali po pozivu novoformirane Kadareve vlade („revolucionarna radničko-seljačka vlada“). Na tajnom sastanku održanom na Brionima u noći 2/3. novembra sovjetska delegacija Hruščov-Maljenkov dogovorila je sa jugoslovenskom stranom u kojoj su bili Tito, Kardelj, Ranković 
i ambasador u Moskvi Veljko Mićunović sve modalitete predviđene intervencije (zapravo državnog udara organizovanog sa stranom vojskom - N. P.), pa su čak raspravljali i o kadrovskim pitanjima - ko će biti budući premijer! Istovremeno su se javno prikazivali kao veliki prijatelji pobunjenih Mađara i podržavaoci njihovih pravednih težnji za nacionalnom nezavisnošću.

U noći druge intervencije, premijer Nađ i jedan broj njegovih ministara i saradnika pronašli su azil u Ambasadi FNRJ u Budimpešti dok je mađarski kardinal Mindesenti (Mindeszenti) zaštitu potražio kod Amerikanaca. O sudbini azilanata vođeni su pregovori u trouglu Moskva-BudimpeštaBeograd. Dok je trajala opsada jugoslovenskog diplomatskog predstavništva iz sovjetskog bornog vozila rafalnom paljbom usmrćen je jedan službenik Ambasade. FNRJ se zadovoljila relativno mlakim demaršom, neuobičajenim ako se ima u vidu oštrina reagovanja na postupke SSSR-a i njegovih saveznika u drugim prilikama. Konačno, 22. novembra prema sporazumu potpisanom između vlada FNRJ i Mađarske trebalo je da se svi azilanti vrate kućama i da se protiv njih ne vodi postupak. Međutim, pod okolnostima koje su krajnje sumnjive, autobus sa azilantima "skrenut" je sa putanje pa su se svi obreli u sovjetskoj komandi grada. Odatle su Nađ i još nekolicina prebačeni u Bukurešt. Na procesu zatvorenom za javnost Nađ je osuđen na smrt i potom pogubljen, zajedno sa još nekoliko optuženih. FNRJ je uložila protest smatrajući da su njena prava kao države - jemca azila povređena. Još izvesno vreme trajalo je propagandno prepucavanje na relaciji Moskva i Budimpešta sa jedne i Beograd sa druge strane, objavljivanje optužujućih knjiga raznih boja (sa vešto odabranim dokumentima koja treba da potkrepe „našu" istinu) i oštrih novinskih komentara. U svakom slučaju Mađarska 1956. predstavlja jednu od bitnijih tačaka u igri zvanoj „hladni rat“ i rašrafljivanju komunističkog sveta, a u njoj je očigledno značajan ako ne i bitan udeo imala igra jugoslovenskih državnih i vojnih organa koja ni do danas nije $\mathrm{u}$ potpunosti razjašnjena. ${ }^{1}$

Uporedo sa burnim političkim događajima, krajem 1956. i početkom 1957. u Budimpešti se odigravala zanimljiva obaveštajna afera koju smo simbolično označili filmskim naslovom jer je reč o „poduhvatu“ dostojnom

${ }^{1}$ O ustanku u Mađarskoj oktobra-novembra 1956. postoji ogromna literatura. Za jedan deo videti: Nenad Ž. Petrović, Depeše Jugoslovenskog vojnog izaslanika iz Budimpešte 1956-1957. godine, Vojnoistorijski glasnik, 1-2, Beograd 2007, nap. 2 i 3 na str. 181-182. Takođe poglavlje „Burna 1956. godina: Dvadeseti kongres KPSS, Titova poseta SSSR-u i pobuna u Mađarskoj“ u projektu Instituta za strategijska istraživanja autora Nenada Ž. Petrovića, Jugoslovensko-sovjetski vojnopolitički odnosi 1953-1964. godine, 64-130 rukopisa. (U obradi ove teme izbegavali smo pojmove revolucija odnosno kontrarevolucija jer oni nose unapred vrednosnu kvalifikaciju pa smo stoga odabrali neutralnije izraze pobuna, ustanak, revolt...). 
holivudskog filma o „agentu 007“. Ta akcija krađe visokosofisticirane vojne tehnologije i prebacivanja grupe mađarskih inženjera u Jugoslaviju prepliće se sa dramatičnim događajima vezanim za obaranje vlade Imre Nađa i ugušenjem pobune ali poseduje i posebnu, ljudsku dimenziju. Dokumenti koji slede pokazaće koliko se jugoslovenska vojno-obaveštajna služba sa uspehom okoristila smutnim vremenima i prilikama nastalim u Mađarskoj 1956. godine.

Posle druge sovjetske vojne intervencije $3 / 4$. novembra prilike $\mathrm{u}$ Budimpešti i celoj Mađarskoj su postepeno normalizovane. Upravo u to vreme jugoslovenski vojni i diplomatski predstavnici, inače vrlo agilni u vreme same krize, preko pukovnika Gabora Nađa (Gabor Nagy), koji je od ranije sarađivao sa jugoslovenskom službom i krajem 1956. ili na samom početku 1957. prebegao u Jugoslaviju, ${ }^{2}$ došli su u kontakt sa grupom vojnih konstruktora voljnih da prebegnu. $\mathrm{O}$ tome govore naredne depeše. ${ }^{3}$

„Br. 177/25. novembar 1956.

Pukovnik Nađ (bivši komandant PAO) rekao da imaju u fabrici „Gama" najnoviji prototip elektronskog uređaja za gađanje $\mathrm{PA}^{4}$ artiljerije. Komisija sastavljena od glavnog konstruktora, Nađa i još jednog inžinjera usvojila je ovaj prototip. Nađ kaže da PODATKE NISU DALI NITI RUSIMA NITI ČESIMA, I AKO SU SE OVI INTERESOVALI. Izgleda da se radi o uređaju koji u potpunosti rešava problem gađanja aviona koji lete brzinom do $2.800 \mathrm{~km} /$ čas. Uređaj je težak 530 kilograma.

Nađ izneo da bi želeo da se ovaj prototip prebaci u Jugoslaviju, a isto tako i glavni konstruktor (kapetan).

Mi smo mišljenja (zajedno sa Džikićem) da, u koliko Nađ može ostvariti svoju zamisao, preduzmemo sledeće:

a) Da uređaj dopremimo u zgradu ambasade, a zatim na naš šlep na Dunavu - kako bi ga prebacili u zemlju.

b) Konstruktora bi također prebacili u zemlju na neki način - ili ilegalno preko granice ili bi mu dali naš pasoš.

Još nismo sigurni da li se ova stvar može izvesti. O tome ćemo biti obavešteni sutra na sastanku sa Nađem, koji će danas ponovo razgovarati

${ }^{2}$ N. Ž. Petrović, n. r., 192-193, 195. - Depeša vojnog izaslanika JNA iz Budimpešte, br. 3 od 5. januara 1957. traži od Beograda da pukovnik Nađ, kapetan Čiba i drugi mađarski oficiri koji su prebegli u Jugoslaviju pomognu oko rekonstruisanja kartoteke oficira mađarske vojske. Vojno izaslanstvo je takvu kartoteku imalo, ali ju je na početku nereda dobivši naređenje Državnog sekretarijata za inostrane poslove spalilo sa celokupnom dokumentacijom.

${ }^{3}$ Arhiv Vojnoistorijskog instituta, fond JNA, kutija 376, fascikla 1, broj 2 (depeše između Sedmog odeljenja Generalštaba JNA - Vojnog izaslanstva u Budimpešti za 1956. godinu). Sva podvlačenja u depešama su autorova.

${ }^{4}$ Protivavionska. 
sa glavnim konstruktorom. Radi toga molimo da nas hitno obavestite da li se upuštamo u ovu akciju. Drobac ${ }^{5 \text { “ }}$

Sutradan, kao dopunu prethodnog, Drobac je javljao:

„Br. 180/26. novembar 1956.

Danas Nađ nije uspeo da razgovara sa konstruktorom. Dogovorili sastanak za sutra u 15 časova - na koji će doći i konstruktor. Definitivno ćemo znati o čemu se radi posle tog sastanka."

Prvo poimenično spominjanje konstruktora - kapetana mađarske vojske, sreće se u depeši koja nosi oznaku najveće poverljivosti (DDD):

„Br. 182/27. novembar 1956.

Danas razgovarali sa Nađem i konstruktorom Daru Janosom ${ }^{6}$ - veza naš 177. Daru je bio naučnik artiljerijskog istraživačkog instituta. Imao je svoju konstruktorsku grupu od 12 inžinjera. Za vreme rata radio je za MESSERSCHMIDT, gde je počeo da se bavi problemom elektronskog uređaja za $\mathrm{PAA}^{7}$. Poslednjih 7 godina radio je na elektronskom uređaju koga na engleskom naziva „GUN CONTROL EQIPEMENT“ - što znači na ruskom „PUAZO“8. Od 1952. dobio je punu podršku za svoj rad. Uređaj je završen nedavno i eksperimenti su pokazali da je u osnovi uspeo, iako ima nedostataka koje treba ispraviti. Tvrdi da je ovaj uređaj bolji od sličnog koga imaju Rusi, koji su bili jako zainteresovani za njegov pronalazak - jer im je potrebno 40.000 komada za njihovu armiju. Takođe tvrdi da ni na Zapadu ne postoji bolje rešenje ovog problema. Proizvodnja mađarskog G. C.E. ${ }^{9}$ košta oko 10.000 dolara, a ruskog oko 2 miliona rubalja. Rusi su dobili neke planove još za vreme istraživanja, ali ti planovi su kasnije izmenjeni, tako da oni sada ne poseduju ništa. Njegov kolektiv smatra da će se u Mađarskoj ovaj uređaj moći proizvoditi tek kroz dve godine. Radi toga bilo je predloga da se uređaj stavi na raspoloženje Jugoslaviji, Poljskoj ili Kini, što ga je ponukalo da se preko pukovnika Nađa poveže s nama. Juče se pomoćnik ministra industrije Kolos Rihard ${ }^{10}$ interesovao za uređaj i njegov rad. Rekao mu je da će se rad na istraživanju nastaviti. Pretpostavlja da će se uskoro zainteresovati

${ }^{5}$ Potpukovnik Milan Drobac, vojni izaslanik JNA u Budimpešti.

${ }^{6}$ Daru Janoš.

${ }^{7}$ Protivavionska artiljerija.

${ }^{8}$ Verovatno je reč o ruskoj skraćenici za ovaj aparat. Engleski izraz je pogrešno napisan, trebalo bi da stoji equipment. Po svoj prilici, reč je o elektronskoj opremi za navođenje protivavionskih raketa.

${ }^{9}$ Gun control equipment.

${ }^{10}$ Kološ Rihard. 
Rusi. Po naređenju iz $\mathrm{MNO}^{11}$ spalio je sve nacrte kada su izbili neredi, tako da jedino on uz pomoć njegovih saradnika može nastaviti rad. Njegov predlog sastoji se u sledećem:

a) Nema potrebe da se uređaj prebacuje u Jugoslaviju.

b) Da je on spreman da ide, ali da treba da ga prate i njegovi saradnici (ceo institut) što znači oko 25 lica sa ženama i decom.

c) Tražio garanciju o zainteresovanosti našeg GŠ, jer ne može da se osloni samo na moju ličnu zainteresovanost.

d) Sa saradnicima nije razgovarao o svom koraku što mora učiniti s ciljem da ih pridobije za svoj plan.

Odgovorili smo mu da se radi samo o mojoj ličnoj zainteresovanosti, da je broj ljudi velik i da je teško sve prebaciti u Jugoslaviju, te da pokuša odabrati najpotrebnije saradnike. Dodali smo da smo imali uvid u samo njega i planove, a eventualno i sam prototip, tako da njegov predlog menja situaciju i zahteva da se razmisli.

Dogovorili smo se da se naknadno sastanemo kroz 2-3 dana i da na osnovu današnjeg razgovora pokušamo naći konkretno rešenje. Nađ je dodao da je on spreman da na sebe preuzme stvar prebacivanja uređaja po delovima iz fabrike na bilo koje mesto u gradu i insistira da se odnese i prototip.

Naš utisak je da se radi o opreznom čoveku i uverenom u vrednost svog pronalaska. Ima dosta pravilne političke poglede. Naglašava da on radi u interesu socijalizma i da se zato povezao sa nama. Suprotstavio se predlozima nekih ljudi da se prototip prebaci na Zapad."

Pregovori sa Daruom i Nađem bili su nastavljeni sledećih dana. Depešom iz Beograda, koja nije sačuvana, predložene su im dve mogućnosti koje je Daru odbacio:

„Br. 192/5. decembar 1956.

1) Samo svoj dolazak smatra izdajom u odnosu na kolege, bez kojih sam ne bi mogao postići tako dobre i brze rezultate, pogotovu što $u$ ovom slučaju ne bi bilo moguće odneti prototip. Nestankom prototipa njegovi inžinjeri bili bi pohapšeni.

2) U slučaju kada bi išla cela grupa prototip bi ostao s tim što bi oni poneli važnije delove i svoje planove (ispostavilo se da sve nacrte ipak nisu spalili).

3) Nije spreman da radi za dve vlade i odbija svaku materijalnu pomoć, jer to njega ne interesuje. U vezi sa ovim izneo kako su Švajcarci pokušali da ga vrbuju preko njegove sestre koja živi u Švajcarskoj, nudili su mu veliku sumu novaca. Ovde smo pogrešili, jer smo ispustili iz vida da se sa

\footnotetext{
${ }^{11}$ Ministarstvo narodne odbrane.
} 
ljudima kao što je Daru ne može razgovarati na način kojim mu se indirektno stavlja do znanja da želimo da ga pretvorimo u agenta. Sve smo nekako izgladili.

4) Kaže da se u Austriji nalazi preko 10.000 emigranata, a velik broj i u Jugoslaviji, ${ }^{12}$ te da njegovo bekstvo ne može imati nikakve političke posledice.

5) Ponovo podvukao da se radi o sasvim novoj naučnoj oblasti elektronici - u kojoj su oni postigli rezultate koji su ih stavili u red stručnjaka svetskog glasa. Rusi imaju ove fabrike za proizvodnju G.C.E., ali njihova proizvodnja je mnogo skuplja, a uređaj težak i nedovoljno usavršen. Sada raspolažu sa oko 2.000 uređaja. Prema Varšavskom ugovoru Mađarska je trebala Rusima da isporuči do 1960. godine 5.000 svojih uređaja, a Istočna Nemačka isto toliko. Počev od 1960. godine oni su nameravali da uređaj plasiraju u Kini. Ako ništa ne bude od njihovog odlaska u Jugoslaviju pokušaće da rade za Kinu. ${ }^{13}$ Savetuje i nama da u tom slučaju legalno kupimo ove uređaje.

6) Nikakve koristi ne bismo imali od njihove tehničke dokumentacije, jer se radi o takvim problemima u kojima se bez njega niko ne bi mogao snaći. Spreman je da nekom našem stručnjaku objasni principe na kojima se zasniva njegov rad. Na kraju rekao da će oni sami pokušati da prebegnu u Jugoslaviju ukoliko mi ne izmenimo stav. Ubeđen da će ga kod nas rado primiti jer se radi o zaista korisnom poslu. Dogovorili smo se o sledećem:

1) Da se ponovo sastanemo u petak 7 o. m. s tim da mu damo definitivan odgovor, posle iznošenja ovih njegovih argumenata. Ne može da shvati naš stav kada je u pitanju ovakva stvar i zato moli da ponovo sve dostavimo Beogradu.

2) Ako naš odgovor bude negativan da se rastanemo kao da nije bilo razgovora, ali da razmotrimo stvar njihovog bekstva bez naše pomoći i učešća što će oni sami do petka ispitati.

Naše je mišljenje da bi ipak trebalo primiti celu grupu, ali da oni sami nađu način kako da pobegnu bez naše neposredne pomoći. Mogli bi im pomoći na granici. Ako se sa ovim slažete molim da nam javite na koji sektor

${ }^{12}$ O izbeglicama videti: Katarina Kovačević, Mađarske izbeglice u Jugoslaviji 1956. godine, Tokovi istorije, 1-2, Beograd 2003, 91-124. - Autorka na osnovu dokumenata iz domaćih i stranih izvora navodi da je preterana brojka od 180.000 mađarskih izbeglica u Austriji koliko neki autori procenjuju. Do ovog broja se došlo svakako zbrajanjem izbeglica iz 1945. sa onima iz 1956 (str. 97 i nap. 25). Za prebegle u FNRJ raspolažemo preciznom statistikom: ukupno 19.857 od čega je 16.374 emigriralo dalje na Zapad, 2.773 se repatriralo (vratilo se u Mađarsku), 634 se nastanilo u Jugoslaviji dok se njih 76 vodilo kao nestalo (str. 98 i 124).

${ }^{13}$ Da li je ovo bila ucena, odnosno pretnja Darua ili je on to ozbiljno mislio? Zvuči neverovatno da bi neko iz Mađarske, nezadovoljan njenim sistemom, odabrao kao utočište Kinu! 
granice da dođu i kako da se prebace. Mislimo da na sledećem sastanku stvar treba okončati. Očekujem odgovor. Drobac"

Prema postignutom dogovoru 7. decembra je održan sastanak sa Daruom. O tome izveštava depeša br. 197 od 8. decembra. Daru je izrazio rešenost da poseti Jugoslaviju i stručnjacima objasni izum a potom da se vrati, ili da jugoslovenski stručnjak istim poslom dođe u Mađarsku. (Iz konteksta ove i sledećih depeša jasno je kako Daru nije odustao od prebacivanja i sebe i cele konstruktorske grupe preko granice). Drobac urgira da Beograd donese definitivan odgovor o ovom pitanju. Ugovoren je sledeći sastanak. Na tom sastanku ponovila su se natezanja: Daru je insistirao da čitava grupa emigrira zajedno sa porodicama (ukupno 22 osobe) što Beograd izgleda nije želeo:

„Br. 199/10. decembar 1956., eksp. 11. decembra u 02,00 h.

Za sada ne može biti govora o tome da ga se privoli da ostane ovde i da sa nama obaveštajno sarađuje. Ovo je sasvim shvatljivo, jer njega gone iz zemlje uslovi i situacija, a ne nedostatak potrebnih sredstava za život./.../ $\mathrm{Na}$ osnovu Vašeg $1367^{14}$ izgleda da se ne razumemo. Osnovno je da mi sada ne znamo šta hoćemo. Ne možemo insistirati na našim uslovima kada su oni za D. neprihvatljivi. Mi smo zainteresovani za stručnjake kao što su D. i ostali, ali izgleda nismo spremni da stvar dovedemo do kraja, pa makar se i kompromitovali u poslu koji zaista opravdava rizik. Sada postoje dve mogućnosti, i to:

a) Organizovati prebacivanje D. i njegove grupe ilegalno preko granice odmah. Ovo učiniti uz pomoć našeg centra u N. Sadu, koji bi obezbedio vodiče i prihvat na granici. Mi ne možemo učiniti ništa. Zabranili ste nam da damo naše pasoše, a brodove na Dunavu kontrolišu Rusi.

b) Ili odustati od namere pod "A“ i čekati povoljniji momenat. Nastaviti sa održavanjem kontakta i pokušati privoleti D. na obaveštajnu saradnju.

/.../ Ako se namerava nešto učiniti u smislu navedenog pod „a“, mislim da bi bilo najbolje da dođem u Beograd da se neposredno dogovorimo, jer ovako ima dosta nejasnosti./.../“

Depeše odaslane u vremenu od 12 . decembra zaključno sa 16 . decembrom potpisivao je Jovo Vukmirović, zamenik vojnog izaslanika, što znači da je Drobac tih dana boravio na konsultacijama u Beogradu kako je i najavio. U tom intermecu počelo je izviđanje terena za ilegalan prelazak za koji je odabran rejon železničke pruge Kelebija-Subotica. Tri inženjera su

${ }^{14}$ Reč je o depeši poslatoj iz Beograda. Za 1956. godinu sačuvane su samo dolazne depeše iz Budimpešte a ne i polazne iz Beograda. 
već otišla u prethodnicu kada je iz Beograda stigla (nesačuvana) depeša kojom je tražena izmena plana bekstva Daruove grupe. Nije bilo vremena da se akcija opozove pa će tako dvojica iz pomenute trojke noću 16/17. decembra preći granicu i javiti se jugoslovenskim organima. Treći će se vratiti u Budimpeštu, kako bi kasnije poslužio ostalima kao vodič za nameravani prebeg tokom noći 19/20. decembra. ${ }^{15}$

Čini se da je konstruktor Daru izgubio strpljenje u natezanju sa jugoslovenskom stranom pa je počeo da deluje samostalno:

„Br. 204/17. decembar 1956.

Plan koji je pripremio Daru za prebacivanje preko granice odgovara dogovoru između Antelja i Drobca. Otsek koji su izabrali - u reonu železničke pruge Kelebija-Subotica - najpodesniji je. Inžinjeri Hollo Pal i Mucsi Sandor ${ }^{16}$ trebali su da pređu granicu noću između 16 i 17, što pokazuje da je D. rešen da svoju nameru izvede bez obzira na naše uslove. Molimo da nas obavestite da li su ova dva inžinjera stigla i da li je Antelj stupio s njima u vezu, jer postoji mogućnost da ih drugi naši organi odvedu u svoja prihvatilišta. Pokušaćemo da se večeras sastanemo sa D. (iako sastanak ugovoren za sutra) i da pokušamo uticati u smislu dogovora. U svakom slučaju saznaćemo njihov plan i namere o čemu ćemo obavestiti. Molimo da se javi Antelju da noću između 19 i 20 om. (SIC) očekuje grupu na dogovorenom mestu - sektoru. U ovakvoj situaciji, naime ako se plan bude odvijao po zamisli D., neće biti potrebno da koristimo naše baze i vodiče. S druge strane eliminiše se mogućnost našeg kompromitovanja, jer čitavu stvar ne organizujemo mi već D. sam. Pored Darua, Nađa i pomenute dvojice u grupi će se nalaziti i sledeći: Barta Gyula, Csok Imre, Nemet Ferenc, Csapkovic Jene, Vas Janos, Pap Istvanne, Misanygy Robert i Farkas Imre. ${ }^{17}$ Nije sigurno da će poći svi ovi ljudi. Drobac"

Kao produžetak ove depeše vojni izaslanik je samo nekoliko časova kasnije javio:

„Br. 206/17. decembar 1956.

Večeras razgovarali sa D. Dva inžinjera, kako je to javljeno našim brojem 204, trebali su da pređu granicu između 16 i 17 o. m. Umesto Muči Šandora granicu je prešao Barta Imre /.../ Do granice trebao ih je da prati (SIC) jedan inžinjer koji će sutra poslati obaveštenje kako je stvar uspela. Četvrti se vratio u Budimpeštu danas i podneo D. izveštaj o stanju na grani-

\footnotetext{
${ }^{15}$ Videti depeše br. 201/13. decembra i 203/15. decembra 1956.

${ }^{16}$ Holo Pal i Muči Šandor.

${ }^{17}$ Barta Đula, Čok Imre, Nemet Ferenc, Čapković Jene, Vaš Janoš, Pap Ištvan, Mišanj Robert i Farkaš Imre.
} 
ci i uslovima prelaska, koji je javljen. Imaju u Kelebiji svog čoveka, koji će ih voditi do granice. Ako sutra dobiju povoljne vesti od inžinjera koji je ostao u Kelebiji nameravaju da po grupama svi krenu vozom za Kelebiju. Ovaj voj polazi iz Budimpešte u 7.30. Kreću po ranijem planu u sredu 19 om. tako da će granicu preći odmah padom mraka na sektoru $1 \mathrm{~km}$ istočno od pruge i $2 \mathrm{~km}$ zapadno od pruge. Mole da ih obavestimo sutra da li su pomenuta dvojica stigla. Molimo hitno nam javite, da bi im to mogli reći sutra u 17 časova kada će Nađ predati Jovi stvari o kojima je već bilo reči. ${ }^{18} \mathrm{D}$. večeras dao neke svoje priručnike i fotografije materijala iz oblasti elektronike. Nismo uspeli u pokušaju da D. nagovorimo da smanji grupu./.../ Uverili smo ga da će svi biti primljeni i da je bolje da o uslovima rada razgovaraju u Jugoslaviji. Ponovo istakao da sa njim idu najbolji stručnjaci koje ima Mađarska u oblasti elektronike. Cela grupa sa ženama treba da broji oko 17 lica. Neshvatljiv mu je naš stav. Smatra da za desetak porodica nije problem obezbediti uslove života i rada. Pri tome naravno on nije u stanju da sagleda politički problem čitave stvari. /.../"

Konačno, dolazi do finalizacije „radova“:

„Br. 207/18. decembar 1956.

Večeras u 17.00 časova Nađ̈ predao Jovi kofer sa delovima G.C.E., koji se sada nalaze kod nas u kući. Treći inžinjer iz Kelebije obavestio D. da krene 19 ujutru. Granicu će preći noću između 19 i 20 ukupno 7 ljudi sa Daruom i Nađem. S njima će biti i žene. Još tri inžinjera, koji se nalaze u provinciji, prema njihovom planu, preći će granicu 20 i 21 om. Kako smo već javili našim brojem 206 naš pokušaj da grupu smanjimo nije uspeo. Ovim je deo našeg posla završen. Želimo da ukažemo na neke momente koji mogu uticati na dalji postupak sa ovim ljudima. U institutu vlada mišljenje da su mnogi inžinjeri hteli pobeći na zapad, tako da se dugo vremena neće znati gde se ovi stvarno nalaze. Kad se sazna da je nestao D. sa grupom glavnih inžinjera, nastupiće traganje od strane Mađara, a verovatno i Rusa. Da bi se kamufliralo naše učešće u čitavoj stvari, mislimo da bi bilo dobro da se bar dve grupe od po tri-četiri inžinjera prijave u kratkim vremenskim razmacima mešovitoj komisiji za repatrijaciju - pred kojom bi izjavili da se ne žele vratiti u Mađarsku. Možda mogu izjaviti da žele ići na Zapad, a kasnije se mogu „predomisliti“ i ostati u Jugoslaviji. Neki mogu reći pred ovom komisijom da će ${ }^{19}$ eventualno vratiti i u Mađarsku, ali kasnije kada se prilike srede i. t.d. Ako bi se sve ovo vešto iskombinovalo postigle bi se dve stvari:

\footnotetext{
${ }^{18}$ Reč je o delovima elektronskog aparata.

${ }^{19}$ Ispušteno: se.
} 
a) Pokazalo bi se da mi dolazak inžinjera ne krijemo, što bi svakako učinili da smo mi organizovali njihovo bekstvo.

b) Stvorili bi utisak o nejedinstvenosti grupe što bi opet išlo u korist kamufliranja našeg delovanja.

Materijal koji smo dobili prebacićemo u Beč, te dati Radovanoviću. To ćemo verovatno učiniti već u četvrtak 20 om. Mislimo da je bolje zbog eventualne kontrole.

Molimo da nas obavestite o stizanju D. i ostalih. Drobac"

Depeše za 1957. godinu sačuvane su u oba smera: Budimpešta-Beograd i obratno. ${ }^{20}$ Depeše iz te godine vezane za poduhvat „Gama“ bave se uglavnom sudbinom žene-inženjera Ištvane Pap, koja se iz porodičnih razloga predomislila i ostala u zemlji. Neuspešno su se okončali svi pokušaji da se i ona naknadno privoli na emigraciju. Pod naznakom najveće hitnosti, Beograd izveštava vojnog izaslanika u Budimpešti:

„Br. 45/10. januar 1957.

Ing. Pap Ištvane (žena) radi u fabrici „Gama“ /.../ Ona je stručnjak iz grupe D. i neophodna za rad. Potrebno je da se što pre prebaci kod nas. Telefon $\mathrm{u}$ fabrici radi samo petak i subota ukoliko se to nije izmenilo. $\mathrm{Na}$ stanu telefon bio pokvaren, mislim da je popravljen.

Kontakt uspostavite preko javne govornice i recite joj „da je D. pozdravlja i želi da se što pre vide."

Neka krene istim kanalom sa čitavom porodicom i javi približno dan dolaska od kojeg datuma mi nju stalno čekamo radi prihvata.

Lični kontakt ne dolazi u obzir.

$$
\text { Pehaček }^{21 ،}
$$

$\mathrm{Na}$ ovu poruku iz Sedmog odeljenja Generalštaba, vojni izaslanik odgovara iz Budimpešte:

„Br. 8/11. januar 1957.

Našim br. 6 javili smo da organi bezbednosti ispituju slučaj D. i Nađa. Pretpostavimo da su do sada već proveli istragu i u fabrici „Gama“. Nije isključeno da su ispitivali ing. Pap Ištvane koju D. nije uspeo da nagovori za bekstvo - jer je trebala da ide sama, bez porodice./.../ U pogledu uslova bek-

${ }^{20}$ Arhiv Vojnoistorijskog instituta, fond JNA, k. 376, fasc. 1, br. 4 (podvlačenja N. P.).

${ }^{21}$ Rado Pehaček je rođen u Ilirskoj Bistrici, Slovenija, 1913. General-pukovnik JNA. Posle rata šef vojne misije u Berlinu, načelnik Sedme uprave Generalštaba JNA (obaveštajno), komandant korpusa i dr. Odlikovan ordenom Narodnog heroja i drugim visokim odlikovanjima. - Vojna enciklopedija, drugo izdanje, tom 6, Beograd 1973, 617. 
stva situacija je znatno izmenjena. Kontrola je pojačana na železničkim stanicama i u vozovima, tako da je vrlo teško putovati bez ubedljivog razloga./.../ Sve ovo nameće potrebu da se bolje razmisli o ovoj stvari. Mi mislimo da bi trebalo za sada (ili sasvim) odustati od prebacivanja ove porodice jer bi se sukobili sa organima bezbednosti u momentu kada se oni intenzivno bave slučajem D. Da li je uopšte opravdan rizik koji bi smo (SIC) mi preuzeli u ovom slučaju kao slabija strana u odnosu na organe bezbednosti u momentalnoj situaciji./.../."

Nerednih dana razmenjeno je više depeša o bezuspešnom nagovaranju Ištvane Pap da i ona prebegne u Jugoslaviju. I supruga glavnoga prebega Janoša Darua, Katarina, usled bolesti ostala je u Budimpešti.

„Budimpešta, br. 67/4. maj 1957.

Pojedinci iz grupe D. često pišu kolegama u preduzeću gde su radili, ističući svoje bolje uslove i materijalni položaj. Ova pisma utiču da se slučaj D. potpuno ne zaboravi, što može pobuditi pažnju zvaničnih organa, jer kod ljudi u preduzeću unose nervozu i neraspoloženje prema sopstvenom stanju. Trebalo bi preduzeti mere da se ljudi iz grupe D. uopšte ne javljaju kolegama ili ako to čine da vode računa o sadržaju pisama./.../ Katarina se trenutno nalazi u bolnici u BP. ${ }^{22}$ Insistira na odlazak u Jugoslaviju. Preduzela je mere za razvod braka. Molila je da joj pomognemo u napuštanju Mađarske. Tražila i novčanu pomoć, jer nema nikakvih prihoda. Dali smo za nju 1.000 forinti „Zoltanu“".

Krajem jula „Zoltan“ se raspitivao preko svojih veza u pasoškom odeljenju mađarskog MIP-a za mogućnost odlaska Katarine Daru u Beč radi „lekarskog pregleda“. U igri je bila i ideja da se ona uključi u grupu turista posetilaca Zagrebačkog velesajma. Na kraju se konstatuje kako je ipak najrealnija opcija za nju ilegalni prelazak granice! ${ }^{23}$

Poslednja depeša iz 1957. godine koja bi mogla imati vezu sa ovom aferom nosi broj 112 od 2/3. decembra i njome se potvrđuje da je „Zoltan“ primio 10.000 forinti. Namena ovih sredstava nije naznačena.

Godinama posle prebegavanja grupe konstruktora i inženjera tragovi ovog poduhvata pratili su njene učesnike. Tako su se najmanje dvojica iz grupe prebega vratila u Mađarsku. Muči Šandor se sa ženom zadržao u Jugoslaviji dve godine da bi se potom nastanio u SR Nemačkoj odakle se vero-

\footnotetext{
${ }^{22}$ Budimpešta.

${ }^{23}$ Budimpešta-Beograd, br. 94/27. juli 1957.
} 
vatno repatrirao. Barta Đula se takođe repatrirao. Kontaktirao je konzulat FNRJ u Budimpešti i to 1963. godine! Iz Beograda su hladno odgovorili na njegove ponude. ${ }^{24}$

Svakako da bi bilo zanimljivo rasvetliti dalju sudbinu kapetana Janoša Darua i pukovnika Gabora Nađa kao i ostalih konstruktora. Šta je bilo sa aparatom koji su prebacili iz Mađarske? Gde je završio? Da li je elektronska naprava našla primenu u jugoslovenskog vojnoj industriji i naoružanju JNA ili je predata/prodata nekome na Zapadu?Sva ova pitanja čekaju na odgovore koje će dati buduća istraživanja.

Dokumenta koja su ovde izložena otvaraju i niz političkih pitanja, pre svega: Zašto Mađarska nije protestvovala povodom organizovanog prebega svojih stručnjaka u zemlju koju je smatrala prijateljskom?! O ovakvom drskom poduhvatu čak nema ni pomena u brojnim diplomatskim notama razmenjenim na relaciji Budimpešta-Beograd!

Jedina vrsta dovođenja u vezu Jugoslavije sa vojnom fabrikom „Gama" nalazi se uzgredno u opširnom pismu Hruščova (u ime CK KPSS) upućenom Titu i CK SKJ 10. januara 1957. U njemu se spominje jugoslovensko mešanje u događaje u Mađarskoj, pa Hruščov kao primere iznosi neprihvatljivo delovanje Đuke Julijusa (dopisnika Politike) i Gavra Altmana (dopisnika Borbe) koji su istupali po budimpeštanskim fabrikama napadajući vladu Janoša Kadara, a list Mađar so (Magyar Szo ) - glasilo mađarske manjine $\mathrm{u}$ Vojvodini, sa tekstovima $\mathrm{u}$ istom tonu, kolima jugoslovenskog diplomatskog predstavništva dovožen je u više fabrika među kojima je i vojna fabrika "Gama“. ${ }^{25}$

\section{Zaključak}

Špijunaža i obaveštajne afere, industrijske krađe tehnologija i izuma u vojne ili civilne svrhe predstavljaju jedno od znamenja 20. stoleća. Tako je SSSR za nekoliko godina ubrzao izradu svoje atomske bombe zahvaljujući „pomoći“ pojedinih nuklearnih fizičara sa Zapada, idejno opredeljenih za komunizam i svetski mir, koji su u uspostavljanju ravnoteže u atomskom naoružavanju videli spasavanje svetskog mira. ${ }^{26}$ (Da nije prva zemlja provokaciji.)

${ }^{24}$ Isti arhivski fond, 1963, k. 387, fasc. 1, br. 2. (Verovatno su smatrali da se radi o

${ }^{25}$ Arhiv Jugoslavije, fond 507 (CK SKJ), Komisija za međunarodne odnose i veze, SSSR, IX, 119/I-92, list 31 prevedenog pisma na srpskohrvatski.

${ }^{26} \mathrm{O}$ tome videti: David Holloway, Stalin and the bomb. The Soviet Union and Atomic Energy 1939-1956, New Haven, London 1994. - Autor iznosi podatke da bi SSSR i sopstvenim snagama „uradio“ atomsku bombu ali je mogao da ubrza dobivši dragocene podatke, tako da je već krajem 1949. prestao američki četvorogodišnji „monopol“ na atomsko oružje. Ubeđeni komunista nuklearni fizičar Fuks (Fuchs), poreklom nemački Jevrejin, izbegao je u 
socijalizma ovladala ovom tehnologijom SAD bi kad-tad došle $u$ iskušenje da iskoriste svoj monopol u ovom najstrašnijem naoružanju i tako slome i drugi totalitarizam 20. veka. Ipak, „trka u naoružavanju“ za nekoliko decenija svog bezglavog vođenja svejedno je uništila sve ekonomske perspektive svetskog socijalizma i tako dovela do njegovog mirnog urušavanja.)

Osobe koje poverljive podatke ili tehnološke izume otkriju drugoj državi, zavisno od okolnosti, možemo posmatrati kao „zločince iz idealnih pobuda" ili kao izdajnike, kriminalce. Kao idealiste koji potajno rade protiv "svoje“ vlade koju iz političkih, ideoloških, etničkih ili drugih razloga smatraju nehumanom, agresivnom, takvom koja vodi nepravednu spoljnu ili unutrašnju politiku pa stoga ne zaslužuje njihovu lojalnost bez obzira na to što su državljani dotične države; ili se pak sve to radi iz koristoljublja, iz prinuđenosti ucenom.

Takva jedna operacija vođena je krajem 1956. u Budimpešti uskovitlanoj višednevnim nemirima, ubijanjima i pljačkama nastalim kao plod nezadovoljstva Mađara rezultatom Drugog svetskog rata kojim su potpali pod uticaj SSSR-a i bili uključeni u svet socijalizma. Titov režim, koji je ni prvi ni poslednji put $\mathrm{u}$ toku Hladnog rata odigrao dvostruku igru, uspeo je da iskoristi haos nastao privremenim raspadom sistema i vlasti u Mađarskoj da se dočepa vredne vojne tehnologije.

SAD iz Trećeg rajha i bio uključen $u$ „Projekat Menhetn“. Kao takav smatrao je da posle poraza nacizma čini veliku uslugu čovečanstvu jer će sprečiti da sila koja je na svojim plećima iznela ovu borbu bude smrvljena od strane svog dojučerašnjeg saveznika. Iako je sa stanovišta zakona izvršio krivično delo odavanja vojne tajne, smatrao je sebe nevinim. Američki sud $\mathrm{mu}$, naravno, ovo nije uzeo u obzir pa je osuđen na zatvorsku kaznu. 